\title{
Magnesium supplementation to prevent recurrence of renal stones
}

Ivo Laranjinha, Patricia Matias, Jorge Dickson

Nephrology Department, Hospital de Santa Cruz/Centro Hospitalar de Lisboa Ocidental

\section{ABSTRACT}

Stone formers have lower urinary magnesium than healthy people. Higher urinary magnesium levels are associated with lower incidence of kidney stones, and hypomagnesuria has been described as a lithogenic risk factor. Magnesium can have direct and indirect inhibitory effects on lithogenesis: decreasing the absorption of oxalates in the intestine; forming magnesium oxalate complexes which reduces the saturation of calcium oxalate; increasing the urinary citrate and inhibiting the conversion of the calcium oxalate in its monohydrated form. Oral supplementation with magnesium is an effective way to correct hypomagnesuria. However, oral magnesium supplementation in recurrent stone formers with hypomagnesuria is still a subject of ongoing debate, and physicians treating these patients underestimate its potential preventive effects. Oral magnesium supplementation can be used as an adjuvant therapy to the standard prophylactic therapy, mainly in association with an alkali salt. It is well tolerated and has few adverse effects.

Keywords: Nephrolithiasis; Recurrent Stone Formers; Hypomagnesuria; Magnesium supplementation.

\section{INTRODUCTION}

Patients with recurrent stone disease should perform a complete metabolic evaluation. The modifiable lithogenic factors identified in the 24-hour urine analysis will guide therapeutic recommendations to prevent future stone episodes ${ }^{1,2}$. Apart from the efforts to lower calcium (Ca) and oxalate and to increase citrate in the urine, we should look beyond these widely known lithogenic factors.

Low urinary magnesium (UMg) is a quite common finding among recurrent stone formers ${ }^{3}$. In the literature, the prevalence of hypomagnesuria among stone formers varies between 4.3 and $11 \%^{4-8}$, but in some studies it can reach one third ${ }^{9}$. This wide range of hypomagnesuria rate found in the literature is related to the different definitions of hypomagnesuria used.

When compared with healthy controls, stone formers have lower UMg excretion 4,10,11. Epidemiologic studies have found an inverse association between an increased magnesium $(\mathrm{Mg})$ intake and the risk of symptomatic kidney stones ${ }^{12}$.

Healthy children have higher UMg concentrations than healthy adults - mean UMg in adults is $90-104 \mathrm{mg} /$ day and in children is between 120 and $150 \mathrm{mg} / \mathrm{day}^{13-15}$. The higher UMg levels in children's urine has been presented as a justification for the lower prevalence of nephrolithiasis in childhood ${ }^{16}$.

Since UMg is a reasonable surrogate for dietary $\mathrm{Mg}_{\text {intake }}{ }^{17}$, many physicians have hypothesized that increasing Mg intake could increase $\mathrm{UMg}$ and consequently reduce the risk of stone recurrence.

Several studies show that $\mathrm{Mg}$ ingestion in the diet is below the recommended levels - it is estimated that $50-60 \%$ of adults do not reach the average dietary intake ${ }^{18,19}$. A growing body of evidence from epidemiologic and clinical studies has confirmed the association of magnesium deficiency with several diseases such as electrolyte, neurologic, musculoskeletal and inflammatory disorders; cardiovascular diseases and diabetes ${ }^{15,20,21}$.

Increasing dietary $\mathrm{Mg}$ intake can be an effective way to correct a degree of $\mathrm{Mg}$ deficiency; however most of the dietary sources of $\mathrm{Mg}$ also contain important amounts of oxalate, precluding the recommendation of a diet rich in $\mathrm{Mg}$ to all stone formers ${ }^{22}$.

However, oral Mg supplementation to prevent renal stone recurrence is still a subject of ongoing debate, and its potential preventive effects are not proven.

This review summarizes our current understanding of $\mathrm{Mg}$ physiology, the risks and benefits of supplementing stone formers with $\mathrm{Mg}$ and our suggestions for correcting hypomagnesuria in recurrent stone formers.

\section{PHYSIOLOGY OF MAGNESIUM}

Magnesium is mainly eliminated by the kidneys. Although $80 \%$ of the serum $\mathrm{Mg}$ is filtered at the glomerulus, less than $5 \%$ of it is excreted in the urine 23,24 . The renal excretion of $\mathrm{Mg}$ is determined by the rate of filtration and its tubular reabsorption.

The filtered $\mathrm{Mg}$ is reabsorbed by the renal tubules: $10-25 \%$ in the proximal tubule, $60-70 \%$ in the thick ascending limb (TAL) and $5 \%$ in the distal tubule. Transport of Mg in TAL is primarily passive (moving from the lumen to the interstitium) via the paracellular channels, due to a transepithelial gradient generated by the apical $\mathrm{NaK} 2 \mathrm{Cl}$ cotransporter (Figure 1). 


\section{Figure 1}

Physiology of magnesium in the kidney.

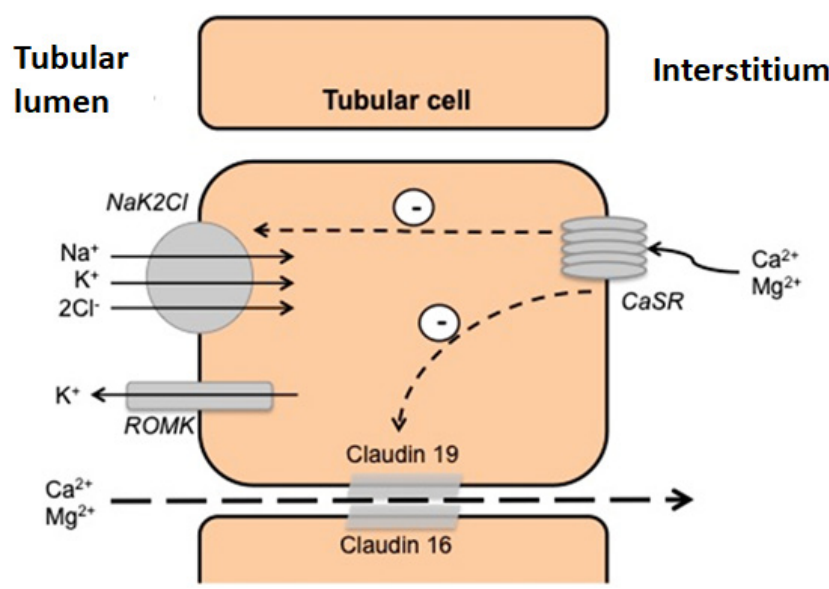

Claudins are transmembrane proteins, an important component of the tight junctions, that regulate paracellular permeability to $\mathrm{Mg}$ and $\mathrm{Ca}$. Claudins variants may change tight junctions' permeability and paracellular reabsorption of $\mathrm{Mg}$ and $\mathrm{Ca}$ driven by the electric gradient generated by potassium-channel (ROMK) and NaK2Cl co-transporter. The calcium-sensing receptor (CaSR) inhibits the expression of claudins in tight junctions and the activity of $\mathrm{NaK} 2 \mathrm{Cl}$, thus decreasing paracellular reabsorption of $\mathrm{Ca}$ and $\mathrm{Mg}$.

The selectivity of the paracellular pathway is determined by claudins which form a cation-selective tight junction through which the $\mathrm{Mg}$ paracellular transport is done 23,24 . Three claudin proteins, claudin-14, claudin-16 and claudin-19, make the cation-selective paracellular pathway for $\mathrm{Ca}$ and $\mathrm{Mg}$. Claudin-16 and claudin-19 form the pores and claudin-14 inhibits the cation selectivity of that pore 25,26 .

Tubular Mg transport is modulated by the extracellular fluid volume and by calcium receptors (CaSR) located in the basal pole of the tubular cells of the TAL, which are sensitive to serum $\mathrm{Ca}$ and $\mathrm{Mg}^{27}$. The activation of these receptors inhibits the $\mathrm{NaK} 2 \mathrm{Cl}$ cotransporter, dissipating the positive transepithelial gradient and decreasing the passive $\mathrm{Ca}$ and $\mathrm{Mg}$ reabsorption, which leads to the increase of $\mathrm{Ca}$ and $\mathrm{Mg}$ urinary losses ${ }^{23,24}$. CaSR also inhibits the phosphorylation of claudins (and unphosphorylated claudins are not expressed in tight junctions) reducing the tight junction permeability to $\mathrm{Ca}$ and $\mathrm{Mg}^{27}$.

\section{GENETICS OF MAGNESIUM IN STONE FORMERS}

Renal stones tend to cluster in families. Studies in twins and families have confirmed the heritability of the nephrolithiasis risk. Genome-wide association studies have identified several candidate genes implicated in renal tubular handling of lithogenic elements, such as calcium, phosphate and oxalate, and inhibitors of lithogenesis, such as $\mathrm{Mg}$ and citrate $^{28}$.

Growing evidence has shown the relevance of the tight junctions (made of claudin paracellular channels) in the regulation of $\mathrm{Ca}$ and $\mathrm{Mg}$ paracellular uptake. Lieske et al. found for the first time a heritable component of the $\mathrm{Mg}$ excretion ${ }^{29}$.
A genome-wide association study suggested that variants in the claudin-14 gene are associated with the ratio of urinary excretion of $\mathrm{Mg}$ and to the urinary stone risk ${ }^{30,26}$.

Claudin-14 knockout mice presented significantly higher serum $\mathrm{Mg}$ and lower fractional excretion rate for $\mathrm{Mg}$ and $\mathrm{Ca}^{31}$. These experimental findings corroborate the genetic data that points to claudin-14 as being a potential culprit of hypomagnesuria in stone formers.

These observations support the fact that genetic defects in claudins expressed in the TAL are part of a spectrum of tubular dysfunction found in stone formers.

\section{RATIONALE FOR MAGNESIUM SUPPLEMENTATION}

Magnesium can have direct and indirect inhibitory effects on lithogenesis (Figure 2). The main mechanisms through which magnesium can inhibit the stone growth are:

- Oral Mg decreases intestinal absorption of oxalate and consequently urinary excretion of oxalate. Oral administration of $\mathrm{Mg}$ binds oxalate in the intestinal lumen, working as an effective oxalate-chelating agent ${ }^{32-34}$.

- Magnesium can also bind oxalate in the urinary lumen and form magnesium oxalate complexes, which are 100 times more soluble than calcium oxalate $(0.07 \mathrm{~g} / 100 \mathrm{ml}$ versus $0.0007 \mathrm{~g} / 100 \mathrm{ml}$, respectively) ${ }^{35}$, lowering the urinary saturation of calcium oxalate

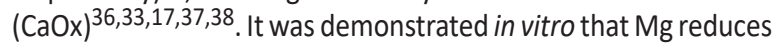
the rate of growth and nucleation of $\mathrm{CaOx}$ crystals 3,37 .

- Magnesium supplementation can increase urinary citrate excretion $^{38,33,39,40,34}$. It has been assumed that magnesium

\section{Figure 2}

The potential mechanisms through which oral magnesium supplementations inhibit calcium stones lithogenesis.

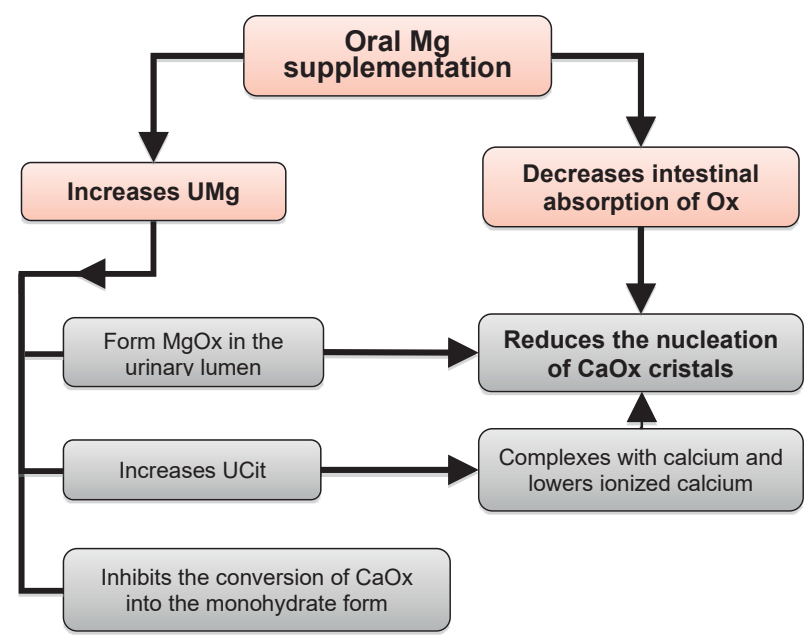

$\mathrm{CaOx}$, calcium oxalate; $\mathrm{Mg}$, magnesium; $\mathrm{MgOx}$, magnesium oxalate; $\mathrm{Ox}$, oxalate and $\mathrm{UMg}$, urinary magnesium. 
supplementation corrects the intracellular acidosis secondary to relative $\mathrm{Mg}$ deficiency leading to the reduction of the proximal tubular re-absorption of citrate ${ }^{41,34}$. Citrate, a well-recognized lithogenic inhibitor, complexes with $\mathrm{Ca}$ and lowers ionized $\mathrm{Ca}$, inhibiting Ca salts precipitation ${ }^{37}$.

- Mg can directly inhibit crystal conversion of $\mathrm{CaOx}$ from the $\mathrm{CaOx}$ dehydrate form into the monohydrate form ${ }^{42-44}$. CaOx monohydrate has a lower solubility, is more stable and more resistant to fragmentation by lithotripsy $45-48$.

\section{IMPACT OF MAGNESIUM SUPPLEMENTATION IN LITHOGENIC FACTOR AND STONE FORMATION}

\section{Urinary magnesium excretion}

Oral supplementation with $\mathrm{Mg}$ salts is an effective way to increase UMg (Table 1) - confirmed in several studies performed in animal models, healthy humans and in stone formers ${ }^{17}$. All the studies in stone formers found a significant increase in the UMg excretion after each $\mathrm{Mg}$ supplementation (Table 1).

In animal models, changes in $\mathrm{Mg}$ amount in diet (with stable $\mathrm{Ca}$ content) significantly modified the Mg urinary excretion. Claudin-14 expression is regulated by $\mathrm{Mg}$ intake. Corre et al. found that a dietary $\mathrm{Mg}$ loading leads to an increase of claudin-14 expression, which blocks the paracellular cation channels made by claudin-16 and claudin-1926 - the mechanism through which Mg supplementation increases the excretion of $\mathrm{Mg}$ in the urine.
The rise in UMg after supplementation can be amplified if the $\mathrm{Mg}$ salt is given with meals instead of taking it on an empty stomach ${ }^{34}$. Also, the combination of $\mathrm{Mg}$ and citrate salts increases the urinary excretion of Mg more than either one supplement alone ${ }^{33,49}$.

The water solubility of an Mg salt is important for its bioavailability. Organic Mg salts (for instance, citrate, gluconate, lactate and aspartate) have a higher water solubility than inorganic salts (for instance oxide and chloride), resulting in a greater intestinal absorption $22,50,51$. In spite of the lack of studies in stone formers, studies in healthy volunteers found that the urinary excretion of $\mathrm{Mg}$ increases more significantly after administration of one of the organic $\mathrm{Mg}$ salts (citrate, lactate and aspartate, were tested) than with $\mathrm{Mg}$ oxide ${ }^{22,51}$. However, even a relatively insoluble $\mathrm{Mg}$ salt can reduce oxalate absorption.

\section{Urinary citrate and $\mathrm{pH}$}

Epidemiologic studies found that patients with lower UMg excretion had significantly lower urinary citrate excretion?

Three of the four studies that evaluate the effect of $\mathrm{Mg}$ supplementation on urinary citrate found that apart from an increase in $\mathrm{UMg}$, there was a concomitant increase in urinary citrate and in urinary $\mathrm{pH}$ (Table 1).

Unsurprisingly, Lindberg et al. ${ }^{34}$ and Pak et al. ${ }^{39}$ found that $\mathrm{Mg}$ citrate causes a higher increase in the urinary citrate than $\mathrm{Mg}$ oxide.

\section{Table 1}

Studies on magnesium supplementation in stone formers.

\begin{tabular}{|c|c|c|c|c|c|c|c|c|c|}
\hline \multirow{2}{*}{ Reference } & \multirow{2}{*}{$\begin{array}{c}\text { Number of } \\
\text { patients }\end{array}$} & \multirow{2}{*}{ Drug and Dose } & \multicolumn{5}{|c|}{ Effect on urinary parameters } & \multicolumn{2}{|r|}{ Effect on stone formation } \\
\hline & & & UpH & UMg & UOx & UCa & UCit & $\uparrow \downarrow$ & Comment \\
\hline Fetner $(1977)^{56}$ & 4 & MgO $1680 \mathrm{mg} /$ day (1000mg of Mg) & $\uparrow$ & $\uparrow$ & $=$ & $\begin{array}{c}\text { 个 } \\
\text { (in 2 } \\
\text { patients) }\end{array}$ & NA & $=$ & $\begin{array}{l}\text { No change in the urinary growth } \\
\text { or formation of } \mathrm{CaOx} \text { or } \mathrm{CaP} \text { cristals. }\end{array}$ \\
\hline Vagelli $(1998)^{32}$ & 9 & $\mathrm{Mg}(\mathrm{OH})_{2} 500 \mathrm{mg} /$ day & NA & $\uparrow$ & $\downarrow$ & $=$ & NA & $\downarrow$ & $\begin{array}{l}\text { Decreases the stone recurrence rate } \\
\text { from } 0.75 \text { to } 0.11 \text { stones/year/patient }\end{array}$ \\
\hline Johanson $(1980)^{40}$ & 90 & $\mathrm{Mg}(\mathrm{OH})_{2} 400-500 \mathrm{mg} / \mathrm{day}$ & NA & $\uparrow$ & NA & $=$ & NA & $\downarrow$ & $\begin{array}{l}\text { Decreases the stone recurrence rate } \\
\text { from } 0.8 \text { to } 0.03 \text { stones/year/patient }\end{array}$ \\
\hline Johanson $(1982)^{53}$ & 98 & $\mathrm{Mg}(\mathrm{OH})_{2} 500 \mathrm{mg} /$ day & NA & 个 & NA & $=$ & 个 & $\downarrow$ & $\begin{array}{l}\text { Decreases the stone recurrence rate } \\
\text { from } 0.8 \text { to } 0.08 \text { stones/year/patient }\end{array}$ \\
\hline Ettinger $(1988)^{58}$ & 82 & $\mathrm{Mg}(\mathrm{OH})_{2} 600$ or $1300 \mathrm{mg} /$ day & NA & 个 & $=$ & $=$ & $=$ & $\downarrow$ & $\begin{array}{l}73.9 \text { and } 62.3 \% \text { fewer calculi formation } \\
\text { than predicted }\end{array}$ \\
\hline Lindberg $(1990)^{34}$ & 11 & $\begin{array}{l}\text { MgCit } 40 \mathrm{mEq} \text { of } \mathrm{K} / \text { day } \\
\text { or } \mathrm{MgO} 40 \mathrm{mEq} \text { of } \mathrm{K} / \text { day }\end{array}$ & $=$ & 个 & $\downarrow$ & $\uparrow$ & 个 & $=$ & $\begin{array}{l}\text { No changes in the urinary saturation } \\
\text { of } \mathrm{CaOx} \text { or } \mathrm{CaP} \text {. }\end{array}$ \\
\hline Reungjui (2002) ${ }^{41}$ & 64 & $0.1 \mathrm{mmol} / \mathrm{L} \mathrm{MgSO}_{4} / \mathrm{kg}$ body weight & $\uparrow$ & $\uparrow$ & NA & NA & $\uparrow$ & NA & - \\
\hline Kato $(2003)^{33}$ & 14 & $231 \mathrm{mg} \mathrm{KNa}-\mathrm{Cit}+250 \mathrm{mg} \mathrm{MgO}$ & $\uparrow$ & $\uparrow$ & $\downarrow$ & $=$ & $\uparrow$ & $\downarrow$ & $\begin{array}{l}\text { Decreases the } \mathrm{CaOx} \text { saturation } \\
\text { (but not the } \mathrm{CaP} \text { saturation) }\end{array}$ \\
\hline Pak $(1992)^{39}$ & 10 & $24.5 \mathrm{mEq} /$ day of $\mathrm{K}$ (KMgCit) & $\uparrow$ & $\uparrow$ & $=$ & $=$ & $\uparrow$ & $\downarrow$ & $\begin{array}{l}\text { Inhibits the crystallization of UA and } \mathrm{CaOx} \\
\text { in urine }\end{array}$ \\
\hline Ettinger $(1997)^{36}$ & 64 & $42 \mathrm{mEq} /$ day of $\mathrm{K}$ (KMgCit) & $\uparrow$ & $\uparrow$ & $\uparrow$ & $=$ & 个 & $\downarrow$ & $\begin{array}{l}\text { Reduces the 3-year recurrence rate of } \mathrm{CaOx} \\
\text { stone formation in } 85 \%\end{array}$ \\
\hline
\end{tabular}

$\mathrm{UpH}$, urinary $\mathrm{pH}$; UMg, urinary magnesium; UCit, urinary citrate; $\mathrm{UCa}$, urinary calcium; $\mathrm{UOx}$, urinary oxalate; $\mathrm{MgO}$, magnesium oxide; $\mathrm{Mg}(\mathrm{OH})_{2}$, magnesium hydroxide; $\mathrm{MgCit}$, magnesium citrate; $\mathrm{KMgCit}$, potassium-magnesium citrate; $\mathrm{MgSO}_{4}$, magnesium sulphate; $\mathrm{CaOx}$, calcium oxalate; $\mathrm{CaP}$, calcium phosphate; “ $=$ ", non-significant change; $\mathrm{NA}$, not available; $\mathrm{K}$, potassium and $\mathrm{UA}$, uric acid. 


\section{Urinary oxalate}

Observational studies have found an association between higher UMg levels and lower rates of hyperoxaluria, suggesting that high $\mathrm{Mg}$ intake can decrease urinary oxalate levels ${ }^{3}$.

Several studies in Ca stone formers ${ }^{32-34}$ found a significant reduction in urinary oxalate excretion with oral $\mathrm{Mg}$ supplementation. In order to maximize the effect of $\mathrm{Mg}$ as an intestinal oxalate-chelating agent, Mg salts should be given with meals ${ }^{34}$. We noted that some of the authors who did not find a significant decrease in urinary oxalate levels during $\mathrm{Mg}$ salts supplementation did not specify if the Mg supplements were taken with meals, which could underestimate the chelating effect of these salts.

Liebman et al. found that $\mathrm{Mg}$ salts (Mg oxide) can be as effective as Ca salts (Ca carbonate) in reducing intestinal absorption of oxalates ${ }^{52}$.

\section{Stone formation - crystallization and stone incidence}

In vitro, $\mathrm{Mg}$ decreases the rate of nucleation and growth of $\mathrm{CaOx}$ crystals ${ }^{17,38}$. Table 1 shows that the great majority of the studies that evaluate the effect of $\mathrm{Mg}$ supplementation in stone formers found a significant inhibitory effect in urine crystallization and/or a significant drop in the stone recurrence rate.

An important fall of the stone recurrence rate was found in the studies that evaluated the stone incidence rate during $\mathrm{Mg}$ supplementation. They found a significant drop in the incident rate from values higher than 0.7 stones/year/patient to an incident rate lower than 0.11 stones/year/patient ${ }^{32,40,53}$ (Table 1).

Allie et al. and Rodgers et al. found a positive synergic effect of the combination of $\mathrm{Mg}$ with citrate on supersaturation of Ca phosphate (lower supersaturation in the combination vs. citrate or $\mathrm{Mg}$ alone) ${ }^{49,50}$. The reduction of $\mathrm{Ca}$ phosphate saturation is favorable since it has been reported that these crystals might provide the nucleus for $\mathrm{CaOx}$ stone formation.

Not all intervention studies with $\mathrm{Mg}$ demonstrate a beneficial effect. We could find several reasons for this: small studies (all studies with less than one hundred patients); different $\mathrm{Mg}$ salts (with different bioavailabilities) were tested; several doses of each salt were used; studies were done on patients with different stone recurrence risk and different levels of Mg deficiency; several studies ignore the indication to take the $\mathrm{Mg}$ supplements with meals and others did not mention the concomitant optimization of the standard stone prophylaxis.

Regarding the effect of magnesium supplementation on calcium phosphate stones prevention, the evidence is even more scarce (or absent). The theoretical preventive effect of magnesium in CaP prophylaxis is based on in vitro experiments that showed a marked inhibitory effect on crystal nucleation, growth and aggregation $54,55,53$.

The few studies that evaluated the effect on $\mathrm{CaP}$ formation in vivo (all with less than 10 patients) did not find a significant change in the urinary saturation ratio, formation or rate of CaP crystal growth with

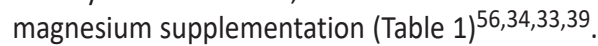

\section{HOW AND WHO SHOULD WE SUPPLEMENT WITH MAGNESIUM?}

It is important to note that $\mathrm{Mg}$ supplementation cannot be recommended for all the stone formers. Most of the stone formers present UMg in the normal range, and an increase in the UMg level will present only a modest inhibitory effect ${ }^{6}$. As Massey ${ }^{6}$ explained, Mg-deficient stone formers who excrete less than $50 \mathrm{mg} /$ day are more likely to benefit from $\mathrm{Mg}$ supplementation.

No studies have compared the different inhibitory lithogenic effect of the several oral Mg supplements available on the market. The most appropriate salts for stone formers supplementation are those that at the same time binds oxalate in the gut and increase UMg and citrate, since they are more likely to reduce the risk of stone recurrence.

Considering the higher bioavailability of organic $\mathrm{Mg}$ salts and the potential synergic effect of $\mathrm{Mg}$ and citrate, $\mathrm{Mg}$ citrate seems to be the most advantageous to inhibit lithogenesis ${ }^{35}$.

Azarfar et al. found that adding Mg salts to the standard nephrolithiasis treatment (with potassium citrate) could add benefit in lowering urinary risk factors ${ }^{35,57}$.

Lindberg et al. found that when Mg supplements were given with meals, apart from a more pronounced reduction in urinary oxalate, there was a more significant increase in $\mathrm{UMg}$ and citrate. This combination was found to be more effective than $\mathrm{Mg}$ salt alone as inhibitor of CaOx crystallization 33,34 .

Thus, Mg supplementation should be recommended as an adjuvant therapy to the standard prophylactic therapy for those patients with high risk of stone recurrence and severe to moderate hypomagnesuria, given as an organic salt during the meal.

\section{ADVERSE EFFECTS OF MAGNESIUM SUPPLEMENTATION IN STONE FORMERS}

The kidney has a good capacity of Mg excretion. So hypermagnesemia generally could occur only when there is an excessive Mg intake/ supplementation in combination with a moderate to severe renal insufficiency. Serum Mg is maintained within the normal range until the glomerular filtration rate falls below $20 \mathrm{ml} / \mathrm{min}$-the remaining nephrons compensate the decline in the Mg filtered by increasing significantly its fractional excretion (reducing its tubular reabsorption) ${ }^{23}$.

The majority of the studies in stone formers found no significant increase in serum Mg levels during long-term Mg supplementation ${ }^{41}$. However, Johansson and colleagues found in two different studies a transitory rise in serum $\mathrm{Mg}$ levels during the first 6-12 months of supplementation, but thereafter the mean value returned to the pretreatment level ${ }^{40,53}$. Nevertheless, no study reported any case of hypermagnesemia or any symptom that could be attributed to it ${ }^{40,53}$. 
The most frequently reported adverse effect of taking oral $\mathrm{Mg}$ supplements was minor gastrointestinal discomfort, namely diarrhea, with a reported frequency from 9 to $17 \% 33,36,40$.

Apart from these common adverse effects of the Mg supplementation common to everyone, one of the main concerns regarding the use of these supplements in stone formers is the risk of hypercalciuria.

Calciuria is modulated by urinary $\mathrm{pH}$ and $\mathrm{Mg}$. Experimental studies suggest that low urinary $\mathrm{pH}$ and high $\mathrm{Mg}$ levels increase calciuria by inhibiting TRPV5/6-mediated Ca reabsorption in the distal nephron ${ }^{17}$.

Although some human studies have found a statistically significant increase of urinary $\mathrm{Ca}$ excretion with $\mathrm{Mg}$ supplementation, this rise in the urinary $\mathrm{Ca}$ did not cause a significant increase in the urinary saturation or stone formation rate (Table 1$)^{17}$.

Kato et al. $^{33}$ found, in healthy volunteers and also in stone formers, that the increase in Ca excretion did not happen if $\mathrm{Mg}$ supplementation was taken concomitantly with citrate. In the same direction, Bonny and colleagues ${ }^{17}$ found that although urinary Ca significantly increases after $\mathrm{Mg}$ salts supplementation alone, its combination with potassium-magnesium citrate did not change significantly the urinary Ca excretion.

These results suggest that Mg supplements should be provided preferentially in the form of $\mathrm{Mg}$ citrate or taken with concomitant urinary alkalinizing agents ${ }^{33,44}$.

\section{CONCLUSIONS}

Hypomagnesuria is frequent in recurrent stone formers and higher UMg levels were associated with lower incidence of kidney stones. Oral $\mathrm{Mg}$ supplementation is an effective way to increase magnesuria in stone formers. Oral Mg supplements have direct and indirect lithogenic inhibitory effects in Ca stone formers, with minor adverse effects. The authors suggest that $\mathrm{Mg}$ supplementation, mainly in association with an alkali salt, is an underestimated weapon in the prevention of Ca stone recurrence. This combination avoids the rise in the urinary Ca and maximizes the inhibitory lithogenic effect, by a greater increase in the urinary citrate and $\mathrm{Mg}$.

Larger, longer and better-designed clinical trials to evaluate the effectiveness of $\mathrm{Mg}$ supplementation in the prevention of stone recurrence are needed. The trial design should include patients with different UMg deficits and should require that the Mg supplement be taken with meals to maximize its benefits.

Disclosure of potential conflicts of interest: none declared

\section{References}

1. Curhan GC, Taylor EN. 24-H Uric acid excretion and the risk of kidney stones. Kidney Int [Internet] 2008;73(4):489-96. Available from: http://dx.doi.org/10.1038/sj.ki.5002708

2. Parks JH, Coe FL. A urinary calcium-citrate index for the evaluation of nephrolithiasis. Kidney Int. 1986;30(1):85-90

3. Eisner BH, Sheth S, Dretler SP, Herrick B, Pais VM. High dietary magnesium intake decreases hyperoxaluria in patients with Nephrolithiasis. URL [Internet]. 2012;80(4):780-3. Available from: http://dx.doi.org/10.1016/j.urology.2012.06.033
4. Raina AF, Bhat MA, Wani I, Kawaja M, Saleem M, Mudasir S, et al. 24-hour urinary constituents in stone formers : a study from Kashmir. Int J Adv Med. 2017;4(5):1477-82.

5. Tefekli A, Esen T, Ziylan O, Erol B, Armagan A, Ander H, et al. Metabolic risk factors in pediatric and adult calcium oxalate urinary stone formers: Is there any difference? Urol Int. 2003;70(4):2737.

6. Massey L. Magnesium therapy for nephrolithiasis. Magnes Res. 2005;18(2):123-6.

7. Schwartz BF, Bruce J, Leslie S, Stoller ML. Rethinking the role of urinary magnesium in calcium urolithiasis. J Endourol. 2002;15(3):233-5.

8. Serra A, Domingos F, Salgueiro C, Prata MM. Avaliação metabólica da litíase cálcica idiopática recorrente em Portugal. Acta Med Port. 2004;17(1):27-34

9. Oğuz U, Resorlu B, Unsal A. Metabolic evaluation of patients with urinary system stone disease: a research of pediatric and adult patients. Int Urol Nephrol [Internet]. 2014 Feb 23 [cited 2019 Apr 12]:46(2):329-34. Available from: http://link.springer.com/10.1007/s11255-013-0539-3

10. Deshmukh SR, Khan ZH. Evaluation of urinary abnormalities in nephrolithiasis patients from marathwada region. Indian J Clin Biochem. 2006;21(1):177-80.

11. Jawalekar SL, Kulkarni UJ, Bhutey A, Mumbai N, Mumbai N, Maharashtra J. Evaluation of different urinary constituent ratios in renal stone formers. Ann Biol Res. 2010;1(3):50-5.

12. Taylor EN, Stampfer MJ, Curhan GC. Dietary factors and the risk of incident kidney stones in men: new insights after 14 years of follow-up. J Am Soc Nephrol. 2004;15:3225-32.

13. Grases F, Rodriguez A, Costa-bauza A, Saez-torres C, Rodrigo D, Gómez C, et al. Factors associated with the lower prevalence of nephrolithiasis in children compared to adults. Urology [Internet]. 2015; Available from: http://dx.doi.org/10.1016/j.urology.2015.06.028

14. Grases F, Rodriguez A, Costa-bauza A. Efficacy of mixtures of magnesium, citrate and phytate as calcium oxalate crystallization inhibitors in urine. J Urol [Internet]. 2015;193(3):812-9. Available from: http://dx.doi.org/10.1016/j.juro.2015.03.099

15. Kesteloot H, Tzoulaki I, Brown IJ, Chan Q, Wijeyesekera A, Ueshima H, et al. Relation of urinary calcium and magnesium excretion to blood pressure. Am J Epidemiol. 2011;174(1):44-51.

16. Simeckova A, Zamrazil V, Cerovska J. Calciuria, Magnesiuria and creatininuria - relation to age. Physiol Res. 1998;47:35-40.

17. Bonny $\mathrm{O}$, Rubin A, Huang $\mathrm{C}$, Frawley WH, Pak CYC, Moe OW. Mechanism of urinary calcium regulation by urinary magnesium and pH. J Am Soc Nephrol. 2008;19(8):1530-7.

18. Costello RB, Elin RJ, Rosanoff A, Wallace TC, Guerrero-Romero F, Hruby A, et al. Perspective: the case for an evidence-based reference interval for serum magnesium: the time has come. Adv Nutr. 2016;7(6):977-93.

19. Workinger JL, Doyle RP, Bortz J. Challenges in the diagnosis of magnesium status. Nutrients. 2018;10(9):1-23.

20. Ismail AAA, Ismail Y, Ismail AA. Chronic magnesium deficiency and human disease; time for reappraisal? QJM An Int J Med [Internet]. 2018 Nov 1 [cited 2019 Sep 16];111(11):759-63. Available from: http://www.ncbi.nlm.nih.gov/pubmed/29036357

21. Razzaque M. Magnesium: are we consuming enough? Nutrients [Internet]. 2018 Dec 2 [cited 2019 Sep 16];10(12):1863. Available from: http://www.ncbi.nlm.nih.gov/pubmed/30513803

22. Rylander R. Bioavailability of magnesium salts - a review. J Pharm Nutr Sci. 2014;4(1):57-9.

23. Musso CG. Magnesium metabolism in health and disease. Int Urol Nephrol. 2009;41:357-62.

24. Cole DEC, Quamme GA. Inherited disorders of renal magnesium handling. J Am Soc Nephrol. 2000;11:1937-47.

25. Hou J. Claudins and mineral metabolism. Curr Opin Nephrol Hypertens. 2017;25(4):308-13.

26. Corre T, Olinger E, Harris SE, Traglia M, Ulivi S, Lenarduzzi S, et al. Common variants in CLDN14 are associated with differential excretion of magnesium over calcium in urine. Pflügers Arch - Eur J Physiol [Internet]. 2016; Available from: http://dx.doi.org/10.1007/s00424-016-1913-7

27. Vezzoli G, Terranegra A, Rainone F, Arcidiacono T, Cozzolino M, Aloia A, et al. Calcium-sensing receptor and calcium kidney stones. J TransI Med [Internet]. 2011;9:201. Available from: http:// www.translational-medicine.com/content/9/1/201

28. Sayer JA. Progress in understanding the genetics of calcium-containing nephrolithiasis. J Am Soc Nephrol. 2017;28(3):748-59.

29. Lieske JC, Wang $X$. Heritable traits that contribute to nephrolithiasis. Urolithiasis [Internet]. 2018;0(0):0. Available from: http://dx.doi.org/10.1007/s00240-018-1095-1

30. Lieske JC, Turner ST, Edeh SN, Smith JA, Kardia SLR. Heritability of urinary traits that contribute to nephrolithiasis. Clin J Am Soc Nephrol. 2014;9(5):943-50.

31. Gong Y, Renigunta V, Himmerkus N, Zhang J, Renigunta A, Bleich M, et al. Claudin-14 regulates renal $\mathrm{Ca}++$ transport in response to CaSR signalling via a novel microRNA pathway. EMBO J [Internet]. 2012;31(8):1999-2012. Available from: http://dx.doi.org/10.1038/emboj.2012.49

32. Vagelli G, Calabrese G, Pratesi G, Mazzotta A, Gonella M. Magnesium hydroxide in idiopathic calcium nephrolithiasis. Minerva Urol Nefrol. 1998;50(1):1-2.

33. Kato Y, Yamaguchi S, Yachiku S, Nakazono S, Hori J-I, Wada N, et al. Changes in urinary parameters after oral administration of potassium-sodium citrate and magnesium oxide to prevent urolithiasis. Adult Urol. 2003;63(1):7-11.

34. Lindberg J, Harvey J, Pak CYC. Effect of magnesium citrate and magnesium oxide on the crystallization of calcium salts in urine: changes produced by food-magnesium interaction. J Urol. 1990;143:248-51.

35. Azarfar A, Esmaeili M, Tousi N, Naseri M, Ghane F, Ravanshad Y, et al. Evaluation of the effects of magnesium supplement in primary and secondary preventions of nephrolithiasis: a systematic review. Rev Clin Med [Internet]. 2016;3(1):16-20. Available from: http://ezproxy.deakin.edu.au/ login?url=http://search.ebscohost.com/login.aspx?direct=true\&AuthType=ip,sso\&db=a9h\&AN=1 $12929467 \&$ site $=$ ehost-live\&scope $=$ site

36. Ettinger B, Pak CYC, Citron JT, Thomas C, Adams-hijet B, Vangessel A. Potassium-magnesium citrate is an effective prophylaxis against recurrent calcium oxalate nephrolithiasis. J Urol. 1997;158:206973.

37. Kolbach-Mandel AM, Kleinman JG, Wesson JA. Exploring calcium oxalate crystallization: a constant composition approach. Urolithiasis. 2015;43(5):397-409. 
38. Khan S, Shevoch PN, Hackett RL. Magnesium oxide administration and prevention of calcium oxalate nephrolithiasis. J Urol. 1993;149:412-6.

39. Pak CYC, Koenig K, Khan R, Haynes S, Padalino P. Physicochemical action of potassium-magnesium citrate in nephrolithiasis. J Bone Adn Miner Res. 1992;7(3):281-5.

40. Johansson G, Backman U, Danielson BG, Fellstrom B, Ljunghall S, Wikstrom B. Biochemical and clinical effects of the prophylactic treatment of renal calcium stones with magnesium hydroxide. J Urol. 1980;124(December):770-4.

41. Reungjui S, Prasongwatana V, Jirakulsomchok S, Sriboonlue P. Magnesium status of patients with renal stones and its effect on urinary citrate excretion. BJU Int. 2002;(90):635-9.

42. Guerra A, Meschi T, Allegri F, Prati B, Nouvenne A, Fiaccadori E, et al. Concentrated urine and diluted urine : the effects of citrate and magnesium on the crystallization of calcium oxalate induced in vitro by an oxalate load. Urol Res. 2006;(34):359-64.

43. Wunderlich W, Ag M. Aspects of the influence of magnesium ions on the formation of calcium oxalate. Urol Res. 1981;9:157-61.

44. Ferrè $\mathrm{S}$, Grange JS, MS BA, Moe OW, Maalouf NM. Effect of urine $\mathrm{pH}$ and magnesium on calcium oxalate saturation. Magnes Res.s. 2018;30(4):107-19.

45. Bon D, Dore B, Irani J, Marroncle M AJ. Radiographic prognostic criteria for extracorporeal shock-wave lithotripsy: a study of 485 patients. Urology. 1996;48(4):550-60.

46. Dretler SP PG. Calcium oxalate stone morphology: fine tuning our therapeutic distinctions. J Urol. 1996;155(3):828-33.

47. Conti C, Brambilla L, Colombo C, Dellasega D, Gatta GD, Zerbi G. Stability and transformation mechanism of weddellite nanocrystals studied by $X$-ray diffraction and infrared spectroscopy. Phys Chem Chem Phys. 2010;12:14560-6.

48. Krambeck A, Lieske J, Mccollough C. Differentiation of calcium oxalate monohydrate and calcium oxalate dihydrate stones using quantitative morphological information from micro-computerized and clinical computerized tomography. J Urol. 2014;189(6):2350-6.

49. Allie S, Rodgers A. Effects of calcium carbonate, magnesium oxide and sodium citrate bicarbonate health supplements on the urinary risk factors for kidney stone formation. Clin Chem Lab Med. 2003;41(1):39-45.

50. Rodgers A. Aspects of calcium oxalate crystallization: theory, in vitro studies, and in vivo implementation. J Am Soc Nephrol. 1999;10(suppl 14):351-4.
51. Ranade V V, Somberg JC. Bioavailability and pharmacokinetics of magnesium after administration of magnesium salts to humans. Am Jounal Ther. 2001;(8):345-57.

52. Liebman M, Costa G. Effects of calcium and magnesium on urinary oxalate excretion after oxalate loads. J Urol. 2000;163(5):1565-9.

53. Johansson G, Backman U, Danielson BG, Fellström B, Ljunghall S. Effects of magnesium hydroxide in renal stone disease. J Am Coll Nutr. 1982;1:179-85.

54. Salimi MH, Heughebaert JC, Nancollas GH. Crystal growth of calcium phosphates in the presence of magnesium ions. Langmuir. 1985;1(1):119-22.

55. Agarwal MM, Singh SK, Mavuduru R, Mandal AK. Preventive fluid and dietary therapy for urolithiasis: an appraisal of strength, controversies and lacunae of current literature. 2011;27(3): 310-9.

56. Fetner CD, Barilla DE, Townsend J, Pak CYC. Effects magnesium oxide on the crystallization of calcium salts in urine in patients with recurrent nephrolithiasis. J Urol. 1977;120:399-401.

57. Guerra A, Meschi T, Allegri F, Prati B, Nouvenne A, Fiaccadori E, et al. Concentrated urine and diluted urine: the effects of citrate and magnesium on the crystallization of calcium oxalate induced in vitro by an oxalate load. Urol Res. 2006;34:359-64.

58. Ettinger B, Citron JT, Livermore B, Dolman LI. Chlorthalidone reduces calcium oxalate calculous recurrence but magnesium hydroxide does not. J Urol. 1988;139(April):679-84.

\section{Correspondence to:}

Ivo Laranjinha, MD

Nephrology Department, Hospital de Santa Cruz/Centro Hospitalar de Lisboa Ocidental

Av. Prof. Dr. Reinaldo dos Santos 2790-134, Carnaxide, Portugal

Mobile phone: 00351 935013798;

E-mail: ivolaranjinha@gmail.com

ORCID: 0000-0001-5895-0680 